\title{
A rare giant sarcoma of the chest wall: Undifferentiated pleomorphic sarcoma
}

\author{
Göğüs duvarının nadir dev sarkomu: Indiferansiye pleomorfik sarkom
}

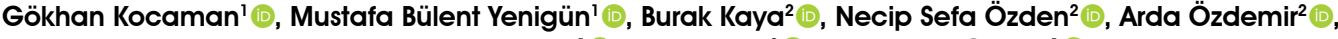 \\ Muhammed Emre Koçak ${ }^{1}\left[\right.$, Hale Kıvrak ${ }^{3}\left[\right.$, Ayten Kayı Cangır ${ }^{1}[$ \\ 'Department of Thoracic Surgery, Ankara University School of Medicine, Ankara, Turkey \\ 2Department of Plastic Reconstructive and Aesthetic Surgery, Ankara University School of Medicine, Ankara, Turkey \\ ${ }^{3}$ Department of Medical Pathology, Ankara University School of Medicine, Ankara, Turkey
}

\begin{abstract}
Undifferentiated pleomorphic sarcoma or, as formerly called, malignant fibrous histiocytoma is a type of sarcoma which originates from fibroblast and histiocytic cells. It is the most common type of sarcoma among all soft tissue sarcomas in adults. Its most common site is the lower limb, followed by the upper limb and the retroperitoneum. It is rarely encountered on chest wall. In the differential diagnosis of masses on chest wall, it is important to consider undifferentiated pleomorphic sarcoma in surgical planning. In this article, we report a male case with a giant undifferentiated pleomorphic sarcoma located above the right scapula.
\end{abstract}

Keywords: Chest wall, malignant fibrous histiocytoma, undifferentiated pleomorphic sarcoma.

Undifferentiated pleomorphic sarcoma (UPS) was first described by O'Brien and Stout ${ }^{[1]}$ in 1964. It usually originates from the deep fascia and the muscles in the lower limbs, but rarely seen on chest wall. ${ }^{[2]}$ It is usually seen in late adulthood, peaking in the fifth and sixth decades of life, and more common in men than in women. ${ }^{[2]}$ In this article, we report a male case with a giant UPS located above the right scapula.

\section{CASE REPORT}

A 71-year-old male patient was presented to the department of thoracic surgery with a giant mass on the right scapular area which was progressively growing for about two years (Figure 1a, b). In his medical history,

\section{$\ddot{O} Z$}

İndiferansiye pleomorfik sarkom veya daha önceki adıyla malign fibröz histiyositoma, fibroblast ve histiyositik hücrelerden kaynaklanan bir sarkom türüdür. Erişkinlerde tüm yumuşak doku sarkomları arasında en yaygın görülen sarkomdur. En sık görüldüğü yer alt ekstremite, ardından üst ekstremite ve retroperitonumdur. Göğüs duvarında nadiren görülür. Göğüs duvarındaki kitlelerin ayırıcı tanısında, cerrahi planlama açısından indiferansiye pleomorfik sarkom düşünülmelidir. $\mathrm{Bu}$ yazıda, sağ skapula üzerinde dev bir indiferansiye pleomorfik sarkom bulunan erkek bir olgu sunuldu.

Anahtar sözcükler: Göğüs duvarı, malign fibröz histiyositoma, indiferansiye pleomorfik sarkom.

there were hypertension, type 2 diabetes mellitus and coronary artery disease, but no history of trauma, foreign body exposure, smoking or radiotherapy that could be a predisposing factor for the occurrence of the mass. In his physical examination, a giant mass about $20 \mathrm{~cm}$ in size, attached to the underlying structures, extending from the right scapula to the axillary area was identified. Also, the skin covering the mass was seen to be erythematous and crusted. There was no palpable axillary or cervical lymphadenopathy. Thoracic computed tomography (CT) revealed as a mass, $16 \times 16 \mathrm{~cm}$ in diameter, extending from the posterior neighborhood of the right scapula to the skin indistinguishable from the muscle plane (Figure 1c).

Received: May 10, 2020 Accepted: September 07, 2020 Published online: October 20, 2021

Correspondence: Gökhan Kocaman, MD. Ankara Üniversitesi Tıp Fakültesi Göğüs Cerrahisi Anabilim Dalı, 06590 Çankaya, Ankara, Türkiye. Tel: +90 312 - 5082917 e-mail: gkhnkcmn@hotmail.com

This paper was presented in the National Pulmonary Health Congress at poster session. March 13-17, 2019, Belek, Antalya, Turkey. Cite this article as:

Kocaman G, Yenigün MB, Kaya B, Özden NS, Özdemir A, Koçak ME, et al. A rare giant sarcoma of the chest wall: Undifferentiated pleomorphic sarcoma. Turk Gogus Kalp Dama 2021;29(4):552-555 

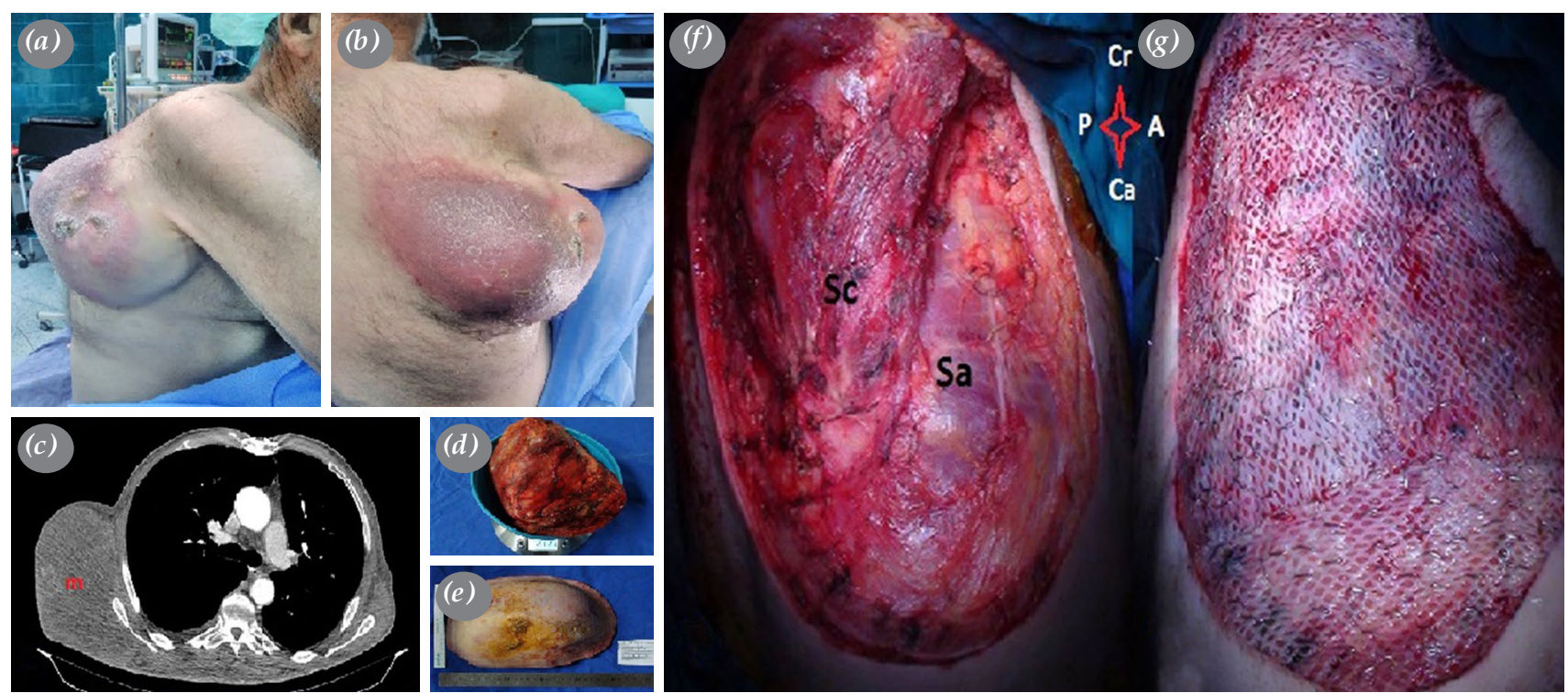

Figure 1. (a) Anterior view of the mass extending through the axilla. (b) Posterior view of the mass. (c) Axial thoracic computed tomography image of the mass. (d) Resection specimen with a tiny fibrous capsule weighing over $2 \mathrm{~kg}$. (e) Resection specimen with a skin margin of $3 \mathrm{~cm}$. (f) Chest wall after resection of the mass. (g) Chest wall meshed with split-thickness skin graft. m: Mass; Sc: Scapula; Sa: Serratus anterior muscle; Cr: Cranial; Ca: Caudal; A: Anterior; P: Posterior.
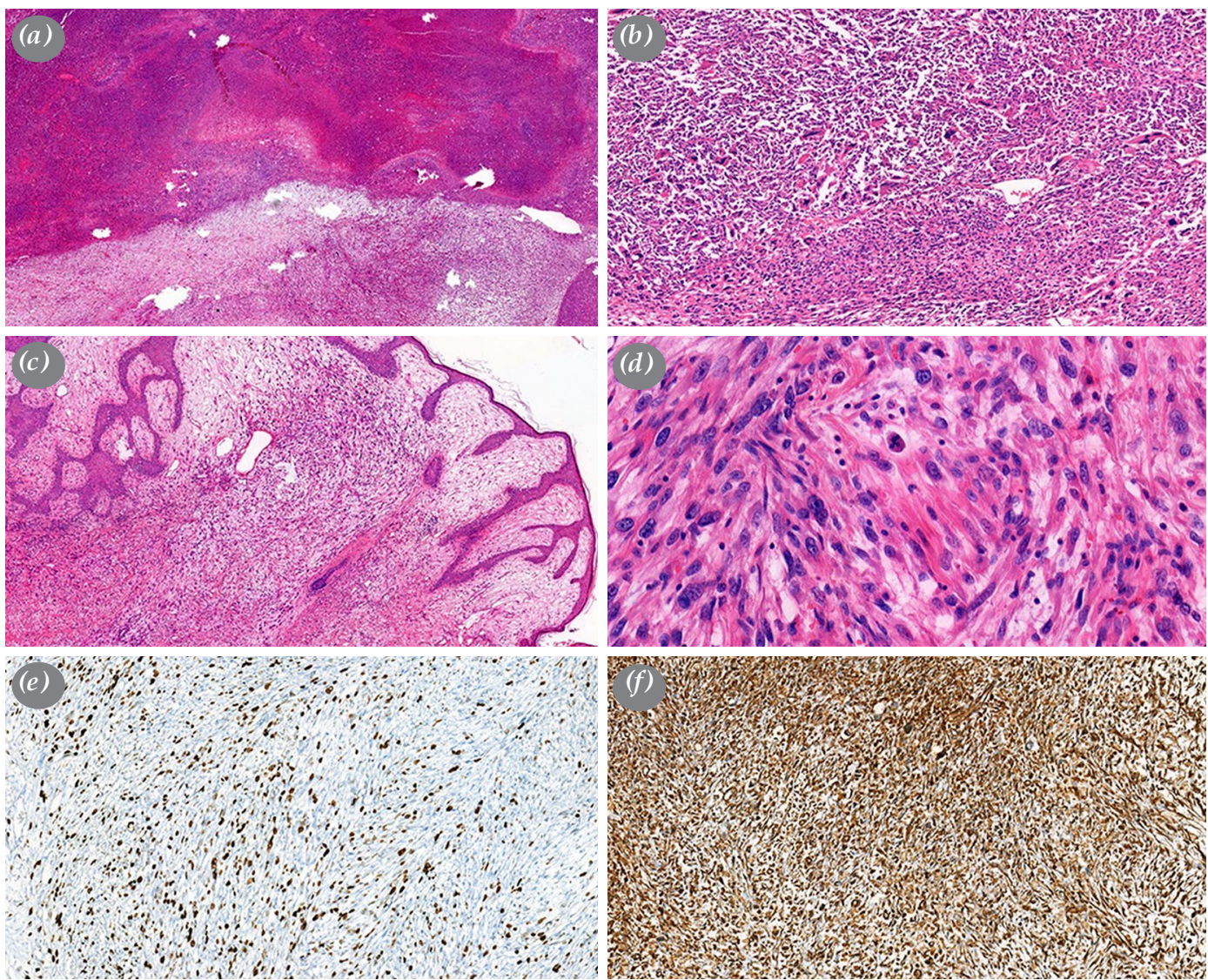

Figure 2. Tumor had storiform and patternless arrangement of highly atypical spindled and polygonal cells. Neoplastic cells exhibited eosinophilic or amphophilic cytoplasm and bizarre nuclei. Abundant mitoses, often with abnormal forms, focal myxoid stromal change and coagulative necrosis were seen $(\mathbf{a}-\mathbf{c})(\mathrm{H}-\mathrm{E}, \times 50)$, (d) $(\mathrm{H}-\mathrm{E}, \times 400)$. (e) The Ki67 proliferation index was 35\%. (f) Tumor cells showed only vimentin expression. 
On the positron emission tomography (PET)-CT scan, the maximum standardized uptake value (SUVmax) of the lesion was 12. Cranial CT showed no metastatic disease. Tru-cut biopsy result reported as a spindle cell tumor. Based on all these findings, an operation was planned to excise the mass. A written informed consent was obtained from the patient.

At this stage, the patient was prepared for mass excision and repair of the defect with a meshed splitthickness skin graft (STSG) at a 1:1.5 ratio under general anesthesia. Complete blood count, complete biochemistry, coagulation parameters, and viral marker tests were within normal limits. The operation was initiated by giving the patient a left lateral decubitus position. Leaving $3 \mathrm{~cm}$ of healthy skin margin from the erythematous borders of the mass, the mass was resected from the dorsal surface of scapula and from the anterior fascia of the serratus anterior muscle with some fibers of the latissimus dorsi muscle and also with the affected skin in an en bloc fashion. Tumor weight was $2.132 \mathrm{~g}$ and the long diameter of the tumor was $20 \mathrm{~cm}$ (Figure 1d, e). The STSG taken from the right anterolateral thigh was first meshed at a ratio of 1:1.5 and, then, adapted to the defect (Figure 1f, g). The operation was completed with appropriate bolster dressing. Gross examination showed a circumscribed light tan and firm mass which had fibrous capsule

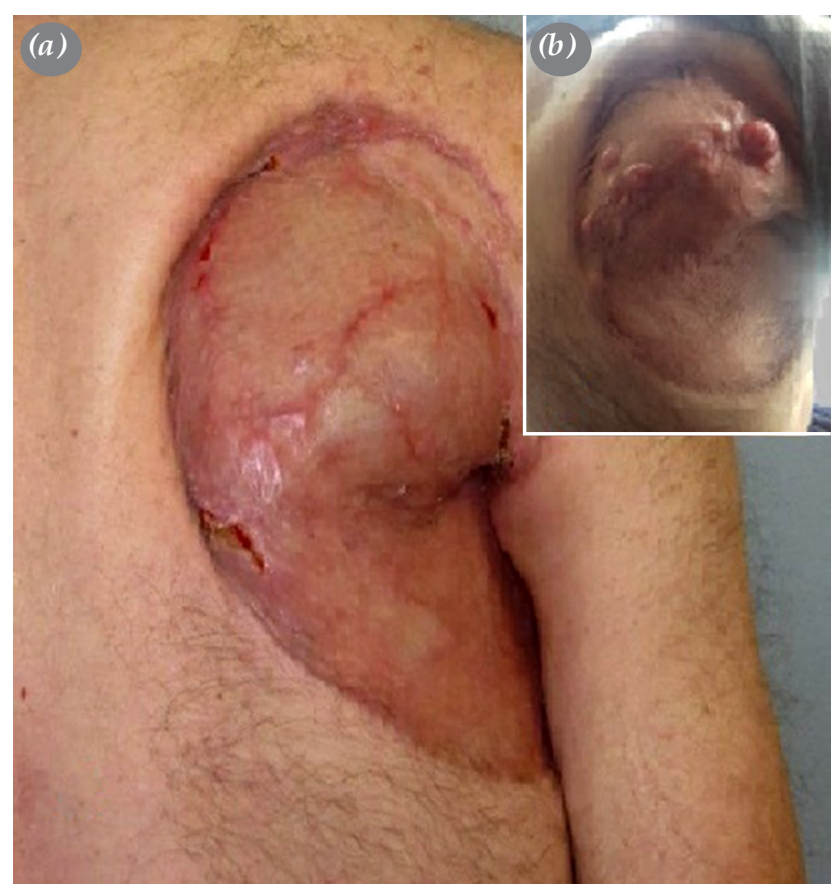

Figure 3. (a) Well wound healing after two months. (b) Local recurrence after six months. and myxoid cut surface. Pathological diagnosis was reported as an UPS. As excepted, histomorphology of the UPS was characterized by spindle cell, focal myxoid change, high cellularity with nuclear pleomorphism. There were abundant mitotic activity and necrosis. There was no discernible microscopic evidence of any specific form of differentiation. Tumor cells showed vimentin expression only and Ki67 proliferation index was $35 \%$ (Figure 2).

The patient was followed with vacuum-assisted closure therapy for 10 days. He was discharged on Day 14 without any complications. The patient did not accept any adjuvant treatment. He had good wound healing after two months, but local recurrence was observed six months after surgery (Figure $3 a, b)$. The patient received chemoradiation therapy for recurrence and still alive without any progression during 15-month follow-up.

\section{DISCUSSION}

Undifferentiated pleomorphic sarcoma is the most common soft tissue sarcoma in adults with an uncertain origin. The usual manifestation is painless, rapidly growing and palpable masses. ${ }^{[2]}$ The present patient was a 71-year-old male with clinical findings consistent with the literature.

In their retrospective series of 167 cases, Kearney et al. ${ }^{[3]}$ reported that $51 \%$ of UPSs were located in the lower extremity (particularly in thighs), $24 \%$ in the upper extremity, $9 \%$ in the retroperitoneum, $9 \%$ on the lower trunk, and $7 \%$ on the upper trunk. Weiss and Enzinger ${ }^{[2]}$ reported that the tumor involved deep fascia at a rate of $19 \%$, skeletal muscle $59 \%$, subcutis without fascia $7 \%$, and retroperitoneum $15 \%$. They reported local recurrence in $44 \%$ and distant metastases in $42 \%$ of the cases. King et al..$^{[4]}$ published their 90 patients of chest wall resection series in 1986. Undifferentiated pleomorphic sarcoma was the most frequent histological type among malignant chest wall tumors (26.8\%) and UPS had worse overall survival than chondrosarcoma and rhabdomyosarcoma. They recommended a $4-\mathrm{cm}$ resection margin instead of $2 \mathrm{~cm}$ for UPS-like high grade tumors due to high local recurrence rates. Yoshida et al., ${ }^{[5]}$ in their review of 39 chest wall UPS cases from Japan, reported that wide surgical resection with negative margins, irrespective of resection margin diameter, was mandatory for better recurrence free survival. Matsumoto et al. ${ }^{[6]}$ reported that an intact margin of $1 \mathrm{~cm}$ was sufficient for other primary tumors, but an intact margin of $5 \mathrm{~cm}$ was required for recurrent or infiltrative type UPS. In our presented case, a 3-cm intact skin margin was left and 
excision was made over the serratus fascia by including latissimus dorsi muscle and paravertebral muscles. Lateral surgical margin seems to be insufficient, but it was measured from erythematous borders of the mass and pathologically there was a 4-cm tumor-free margin. The problem was about the deep surgical margin. The mass had a tiny fibrous capsule and it was resected with the neighbor muscle fibers, but for adequate deep surgical margin; scapula resection and anterior chest wall resection were needed. We thought that it would be too morbid or possibly a mortal operation for a 71-year-old patient with serious comorbidities.

The prognostic factors known to be associated with survival in malignant fibrous histiocytoma patients include tumor stage, depth, tumor size, presence of metastasis, patient age and histological subtype. ${ }^{[7]}$ Our patient had nearly all the unfavorable prognostic factors: an elderly man with comorbidities, a big deepseated tumor with high stage (Stage IIIB according to $8^{\text {th }}$ Edition of the American Joint Committee on Cancer Staging System for Soft Tissue Sarcoma of the Trunk and Extremities), but he is still alive although he had recurrence. ${ }^{[8]}$

Our case did not receive any neoadjuvant chemotherapy and/or radiotherapy, as the tumor was resectable, the skin over the mass was infiltrated and, with neoadjuvant treatment, it could progress to necrosis and, then, could be infected. At least adjuvant radiotherapy could be given for local control due to the narrow deep surgical margin, but the patient refused any kind of adjuvant treatment.

In conclusion, undifferentiated pleomorphic sarcoma is an aggressive tumor and rarely seen on chest wall. Age, tumor size, and tumor stage should not preclude surgery. Wide excision with negative surgical margins is the primary treatment and it could be achieved, regardless of the mass diameter. If surgical margins are close, even they are negative, adjuvant radiotherapy may be beneficial to avoid local recurrence.

\section{Declaration of conflicting interests}

The authors declared no conflicts of interest with respect to the authorship and/or publication of this article.

\section{Funding}

The authors received no financial support for the research and/or authorship of this article.

\section{REFERENCES}

1. O'Brien JE, Stout AP. Malignant fibrous xanthomas. Cancer 1964;17:1445-55.

2. Weiss SW, Enzinger FM. Malignant fibrous histiocytoma: An analysis of 200 cases. Cancer 1978;41:2250-66.

3. Kearney MM, Soule EH, Ivins JC. Malignant fibrous histiocytoma: A retrospective study of 167 cases. Cancer 1980;45:167-78.

4. King RM, Pairolero PC, Trastek VF, Piehler JM, Payne WS, Bernatz PE. Primary chest wall tumors: Factors affecting survival. Ann Thorac Surg 1986;41:597-601.

5. Yoshida N, Miyanari N, Yamamoto Y, Egami H. Successful treatment of malignant fibrous histiocytoma originating in the chest wall: Report of a case. Surg Today 2006;36:714-21.

6. Matsumoto S, Ahmed AR, Kawaguchi N, Manabe J, Matsushita Y. Results of surgery for malignant fibrous histiocytomas of soft tissue. Int J Clin Oncol 2003;8:104-9.

7. Liu Y, Chen G, Wu Y, Liu R, Xu S, Chen J, et al. Combined pulmonary lobectomy for surgical treatment of a malignant fibrous histiocytoma of the chest wall: A case report. Diagn Pathol 2014;9:21.

8. NCCN Clinical Practice Guidelines in Oncology. Soft Tissue Sarcoma. February 2020, Version 6.2019. Avaialble at: https://www.nccn.org/professionals/physician_gls/pdf/ sarcoma.pdf. [Accessed: May 9, 2020] 